ks. Jerzy Adamczyk

Radom

\title{
Choroba celiakii w odniesieniu do sakramentu święceń ${ }^{1}$
}

Kodeks prawa kanonicznego z 1983 roku przypomina i poleca kapłanom, aby pamiętając o tym, że w tajemnicy Ofiary eucharystycznej dokonuje się ustawicznie dzieło zbawienia, często odprawiali Mszę św., a zaleca się usilnie codzienne odprawianie, które, nawet, gdy nie ma wiernych, stanowi czynność Chrystusa i Kościoła. Sprawując ją, kapłani wypełniają swoje główne zadanie (por. kan. 904). Jest to zrozumiałe, gdyż w życiu kapłańskim celebracja eucharystyczna winna zajmować centralne miejsce².

Są jednak sytuacje, w których - mimo że konkretny kapłan pojmuje niezastąpioną wartość, jaką ma dla niego codzienne sprawowanie Mszy św., i pragnie ją przeżywać jako centralną chwilę dnia i codziennej posłu$\mathrm{gi}^{3}$ - może mieć poważne problemy natury zdrowotnej uniemożliwiające mu przyjmowanie Komunii Świętej w sposób zwykły, czyli pod dwiema

\footnotetext{
I Artykuł jest wykładem habilitacyjnym autora.

2 Por. Congregazione per la Dottrina della Fede, Lettera circolare ai Presidenti delle Conferenze episcopali circa l'uso del pane con poca quantità di glutine e del mosto come materia eucaristica, 19 VI 1995, nr III, D, „Notitiae”, R. XXI, 1995, s. 608-610 [dalej: Lettera circolare].

3 Por. Congregatio pro Clericis, Direttorio per il ministero e la vita dei Presbiteri Tota Ecclesia, 31 I 1994, nr 49, Città del Vaticano, 1994, tekst polski: Kongregacja ds. Duchowieństwa, Dyrektorium o postudze i życiu kapłanów, 31 I 1994, Città del Vaticano 1994.
} 
postaciami. Przyjmowanie Ciała Pańskiego może uniemożliwiać choroba celiakii, a przyjmowanie Krwi Pańskiej pod postacią wina - alkoholizm lub inna choroba, w której przyjęcie nawet minimalnej ilości alkoholu stanowi przeciwwskazanie. Przedmiotem niniejszych dywagacji będzie problem celiakii w relacji do sakramentu święceń. Najpierw przedstawi się skrótowo i w formie popularno-naukowej zjawisko celiakii, potem omówi się możliwość przyjmowania Komunii Świętej przez dotkniętych chorobą trzewną, by na koniec, nieco obszerniej, wyeksplikować problem celiakii i dopuszczania do sakramentu święceń.

\section{Zjawisko celiakiii}

Celiakia (choroba trzewna) to trwająca całe życie immunologiczna choroba o podłożu genetycznym, charakteryzująca się nietolerancją glutenu, białka zapasowego zawartego w zbożach (pszenicy, życie, jęczmieniu, owsie). Nieprawidłowa reakcja immunologiczna wywoływana jest nadmierną odpowiedzią immunologiczną na grupę białek zbożowych zwanych prolaminami. Działający toksycznie gluten prowadzi do zaniku kosmków jelita cienkiego, maleńkich wypustek błony śluzowej, które zwiększają jego powierzchnię i są odpowiedzialne za wchłanianie składników odżywczych. W efekcie toksycznego działania glutenu wchłanianie pokarmu jest upośledzone, co prowadzi do wystąpienia różnorodnych objawów klinicznych. Celiakia nie jest alergią, choć często jest z nią mylona. Pierwsze wzmianki o chorobie trzewnej ukazały się w II wieku przed Chr. (Hipokrates i Arateus). Celiakia jest najpoważniejszą nietolerancją pokarmową człowieka.

Patogeneza choroby trzewnej jest niejednoznaczna. Choroba nie jest wrodzona ani dziedziczna, może pojawić się w każdym okresie życia. Szacuje się, że nietolerancja glutenu występuje u 1 proc. populacji. Najczęściej rozwija się we wczesnym dzieciństwie i po 50 roku życia. Częściej występuje u kobiet niż u mężczyzn (2:1). Występowanie choroby u krewnego pierwszego stopnia zwiększa jej ryzyko. O rozwoju celiakii decyduje kilka czynników: genetyczny, metaboliczny, immunologiczny, środowiskowy i prawdopodobnie infekcyjny.

4 Punkt ten opracowano na podstawie: Polskie Stowarzyszenie Osób z Celiakią i na Diecie Bezglutenowej, Celiakia, www.celiakia.pl (1.02.2012). 
Gdy idzie o postacie kliniczne, to choroba trzewna może mieć postać klasyczną (aktywna), występuje u ok. 30 proc. przypadków, objawia się bólami brzucha, wzdęciami, biegunkami tłuszczowymi lub wodnistymi, objawami niedoborowymi składników pokarmowych (m.in. anemia), spadkiem masy ciała, zaburzeniami rozwoju u dzieci (m.in. niskorosłość), zmianami w zachowaniu (m.in. depresja).

W postaci niemej (ubogoobjawowej) - występują typowe zmiany w błonie śluzowej jelita, nie występują jednak objawy choroby aktywnej. Może natomiast pojawić się m.in.: niedokrwistość, próchnica zębów, niedorozwój szkliwa zębowego, nawrotowe wrzodziejące zapalenia jamy ustnej, podwyższony poziom cholesterolu, zaburzenia neurologiczne, otępienie, schizofrenia, upośledzenie umysłowe, wczesna osteoporoza, nawykowe poronienia.

Wreszcie celiakia występuje w postaci ukrytej (latentnej) - mimo że wynik biopsji jelita cienkiego jest prawidłowy. Jednak skąpoobjawowy lub bezobjawowy przebieg nieleczonej choroby trzewnej nie chroni przed wystąpieniem poważnych powikłań, tj. wspomnianej wcześniej niepłodności męskiej, poronień, zaburzeń mineralizacji kości, zwiększonego ryzyka rozwoju chorób o podłożu autoimmunologicznym czy chłoniaka jelita cienkiego.

Gdy chodzi o epidemiologię choroby trzewnej, to określenie częstości jej występowania jest niezwykle trudne. Wynika to z jednej strony z faktu, że publikowane dane są niepełne lub dotyczą jedynie wybranego regionu czy populacji. Z drugiej zaś strony na częstość ujawnienia się celiakii wywierają wpływ lokalne nawyki żywieniowe i związany z tym czas wprowadzenia glutenu oraz jego zawartość w diecie.

Częstość występowania celiakii w Europie i Stanach Zjednoczonych oszacowano od 1: 130 do 1: 350. W Polsce badania epidemiologiczne przeprowadzono w połowie lat dziewięćdziesiątych, a uzyskane dane były zbliżone do innych krajów europejskich: Szwecja 1: 250; Dania 1: 400; Włochy 1: 300; Francja 1: 338; Niemcy 1: 500.

Inne badania szacują, że w Polsce cierpi na celiakię aż 1 proc. populacji. Niestety u nas wykrywa się jedynie niewielki odsetek wszystkich przypadków. Stąd szacuje się, że może być to około 5 proc. Zatem choruje około 380 tys. osób, z czego ogromna większość, bo aż około 360 tys. osób nie jest świadoma choroby.

Obecnie w większości krajów obserwowany jest spadek częstości występowania klasycznej postaci choroby, której objawy wskazano wyżej. Jednocześnie 
zwiększyła się częstość występowania atypowych postaci choroby, celiakii: „niemej” (silent) i „utajonej” (latent), ujawniających się u dzieci starszych lub osób dorosłych ze szczytem zachorowań w czwartej dekadzie życia.

Choroba może ujawnić się w każdym wieku. Zarówno wkrótce po wprowadzeniu glutenu do diety dziecka, jak również podczas dorastania, ciąży u kobiet, dużego stresu itd. Obecnie najczęściej wykrywa się celiakię u osób 30-50-letnich, choć zdarzają się przypadki choroby u osób 80-letnich. Kobiety chorują dwa razy częściej niż mężczyźni.

Mimo rozwoju wiedzy na temat choroby trzewnej, nadal jedyną metodą leczenia pozostaje ścisłe przestrzeganie diety bezglutenowej, polegającej na całkowitej i nieprzerwanej eliminacji z pożywienia pszenicy, żyta, jęczmienia i owsa. Nawet minimalne ilości glutenu $(10 \mathrm{mg}$ w przeliczeniu na gliadynę) w spożywanych pokarmach mogą wywołać nawrót dolegliwości. Należy również pamiętać o produktach, które stanowią tak zwane ukryte źródło glutenu, takie jak konserwy, aromaty, np. w herbatach, skrobia modyfikowana znajdująca się w różnych produktach, przyprawy, ocet spirytusowy. Piwa, w którego produkcji używana jest pszenica, pacjenci spożywać nie powinni.

W przypadku braku leczenia lub leczenia nieskutecznego choroba, oprócz bolesnych objawów, powoduje nieodwracalne uszkodzenie jelita, doprowadzające do zagrażającego życiu niedożywienia.

\section{Choroba trzewna a możliwość przyjmowania Komunii Świętej}

Powstaje w tej chwili pytanie: jaki jest bezpośredni związek celiakii z przyjmowaniem Komunii Świętej pod postacią chleba (opłatka)? Co powoduje, że chory cierpiący na tę dolegliwość nie może przyjmować Chleba eucharystycznego?

Większość naukowców jest zgodna, że u podłoża choroby trzewnej leżą zjawiska immunologiczne zachodzące w błonie śluzowej jelita cienkiego pod wpływem glutenu. Gluten jest frakcją białek, które są obecne w nasionach zbóż europejskich, tj. gliadynie pszenicy, sekalinie żyta, hordeinie jęczmienia. Wspomniany gluten nie jest tolerowany przez organizm chorego, powoduje zaburzenia trawienia i wchłaniania jelitowego.

Tymczasem z woli Chrystusa najświętsza Ofiara eucharystyczna powinna być sprawowana z chleba i wina, do którego należy dodać trochę wody. 
Chleb winien być czysto pszenny i świeżo upieczony, aby nie było żadnego niebezpieczeństwa zepsucia (kan. 924 \$1-2). „Idąc wiernie za przykładem Chrystusa, Kościół w sprawowaniu Wieczerzy Pańskiej stale używa chleba i wina z wodą. Zgodnie z tradycją całego Kościoła chleb do sprawowanej Eucharystii winien być wyłącznie z pszennej mąki, a zgodnie z tradycją właściwą Kościołowi łacińskiemu wymagany jest chleb przaśny" ${ }^{5}$.

Zasady dotyczące przygotowania chleba do celebracji Eucharystii przypomina i szerzej wyjaśnia instrukcja Redemptionis sacramentum:

chleb, którego używa się przy sprawowaniu Najświętszej Ofiary eucharystycznej, powinien być niekwaszony, czysto pszenny i świeżo upieczony, tak aby nie było żadnego niebezpieczeństwa zepsucia. Wynika z tego, że chleb wykonany z innej substancji, nawet zbożowej, lub taki, do którego została dodana znaczna ilość materii różnej od pszenicy, tak że zgodnie z powszechną opinią nie może być nazwany chlebem pszennym, nie stanowi ważnej materii dla sprawowania Ofiary i sakramentu Eucharystii. Poważne nadużycie stanowi dodawanie do chleba przeznaczonego do Eucharystii innych substancji, jakimi są owoce lub cukier czy miód. Jest oczywiste, że hostie winny być wykonywane przez osoby, które odznaczają się nie tylko uczciwością, lecz również mają kompetencje do ich wykonywania i wyposażone są w odpowiednie narzędzia ${ }^{6}$.

Chleb jest produktem spożywczym, otrzymywanym w wyniku wypieku ciasta, stanowiącego jednorodną, plastyczną masę, powstającą z połączenia i wymieszania mąki z wodą, poddanych procesowi fermentacji alkoholowej (drożdżowej) lub mlekowej (bakteryjnej). Rozróżnia się chleb żytni, chleb mieszany żytnio-pszenny oraz chleb pszenny. W niektórych regionach świata wypieka się również chleb z mąki jęczmiennej i owsianej, zaś na obszarach powszechnej uprawy kukurydzy ważnym składnikiem do wypieku chleba jest mąka kukurydziana.

5 Sacra Congregatio pro Sacramentis et Cultu Divino, Instructio Inaestimabile donum, 3 IV 1980, nr 8, „Acta Apostolicae Sedis”, R. 72, 1980, s. 331-343 [dalej: AAS].

6 Congregatio de Cultu Divino et Disciplina Sacramentorum, Instructio Redemptionis sacramentum de quibusdam observandis et vitandis circa Sanctissimam Eucharistiam, 25 III 2004, nr 48, AAS, R. 96, 2004, s. 549-601, tekst polski: Kongregacja ds. Kultu Bożego i Dyscypliny Sakramentów, Instrukcja Redemptionis sacramentum, 25 III 2004, Poznań 2004. 
Ponieważ materią Eucharystii jest chleb wyłącznie z mąki pszennej bez żadnych dodatków, a do natury takiego chleba należy gluten (zawarty w sfermentowanej mące i dlatego również obecny w Chlebie eucharystycznym), stąd chorzy na chorobę trzewną nie mogą przyjmować Komunii Świętej pod postacią chleba. A ponieważ celiakia dotyka stosunkowo duży procent populacji ludzkiej, stąd jest zrozumiałe, że wśród cierpiących na nią są zarówno duchowni, celebrujący Mszę św., jak i wierni przyjmujący Komunię Świętą w czasie Mszy św. czy poza nią.

To prawda, że Komunia Święta jest udzielana w zwyczajnych warunkach pod postacią nie grudki chleba, czy zwyczajnego chleba pszennego, ale opłatka (duże hostie dla celebransa, małe dla pozostałych wiernych), ale ta cienka i mająca tak małą masę hostia zawiera taką ilość glutenu, że jest ona szkodliwa dla chorych. Poświadcza to dokument Przypomnienie w sprawie materii Eucharystii Komisji ds. Kultu Bożego i Dyscypliny Sakramentów Konferencji Episkopatu Polski, gdzie poleca się, aby hostie niskoglutenowe konsekrowano na oddzielnej patenie, a przed udzieleniem Komunii Świętej osobom chorym na celiakię szafarz wypuryfikował palce, gdyby wcześniej dotykał hostii zawierających szkodliwą dla wymienionych chorych ilość glutenu ${ }^{7}$. Typowa hostia komunijna dla rozdania wiernym zawiera między 2,2 a 2,5 miligrama gliadyny, a liczne hostie zawierają między 11,9 a 12,7 miligrama gliadyny, podczas gdy dobowa dawka tego białka dla chorych średnio wynosi ok. 10 miligramów. To w gliadynie obecny jest gluten. Hostie komunijne wytworzone z mąki pszennej mogą powodować bolesne objawy i spowodować histologiczny uszczerbek u pacjentów z celiakiąa .

Znane są przypadki, że chorzy na chorobę trzewną doświadczali wielkich dolegliwości po przyjęciu Komunii Świętej. W liście okólnym pt. Celiakia i hostie eucharystyczne z 16 listopada 1988 roku wysłanym do kard. J. Ratzingera oraz do biskupów Anglii i Australii arcybiskup Liverpoolu Derek John Harford Worlock (4 II 1920 - 8 II 1996) podaje przykłady reakcji osób z chorobą trzewną po przyjęciu Komunii pod postacią chleba. Między

\footnotetext{
7 Komisja ds. Kultu Bożego i Dyscypliny Sakramentów Konferencji Episkopatu Polski, Przypomnienie w sprawie materii Eucharystii, 11 V 2009, nr 10d, „Anamnesis”, R. 16, 2009, nr 3, s. 78 [dalej: Przypomnienie w sprawie materii Eucharystii].

8 Por. J. Wellspring, Coeliac Disease: A New Obstacle to Holy Orders?, „Studia Canonica”, R. 35, 2001, z. 1, s. 195.
} 
innymi 22-letnia kobieta z Kanady, pomimo bycia na diecie bezglutenowej cierpiała na uporczywy ból brzucha i biegunkę. Zauważono, że miało to związek z codziennym przyjmowaniem Komunii Świętej pod postacią opłatka. Kiedy zaczęła przyjmować Eucharystię pod postacią wina, w ciągu dwóch dni objawy minęły. Inny przykład: 8-letni włoski chłopiec z niedoborem wzrostu i defektem jelitowym po sześciu miesiącach bezglutenowego odżywiania pozbył się symptomów właściwych dla celiakii. Począwszy od pierwszej Komunii Świętej zaczął przyjmować Ciało Pańskie raz w tygodniu i wtedy znów pojawił się niedobór wzrostu oraz symptomy wskazujące na uszkodzenie jelita cienkiego. Trzy miesiące później, po tym, jak chłopiec zaniechał przyjmowania Komunii, jego jelito powróciło do normalnego pełnienia swoich funkcji i zniknął niedobór wzrostu?

Wymienione przypadki ukazują szkodliwy wpływ mąki pszennej, z której wypieka się hostie komunijne, na cierpiących na celiakię, co potwierdzają przytoczone wyżej argumenty medyczne ${ }^{10}$.

Jakie więc możliwości przyjmowania Komunii Świętej mają cierpiący na chorobę trzewną? Czy możliwe jest używanie do Eucharystii hostii bezglutenowych? Ponieważ wolą Chrystusa jest używanie chleba pszennego, to jest jasne, że Kościół nie może zmieniać istoty tego chleba. Instrukcja Dominus Salvator noster Świętej Kongregacji dla Sakramentów z 1929 roku przypominała, że „chleb wykonany z innej substancji (nie z pszenicy), nawet zbożowej, lub taki, do którego została dodana znaczna ilość materii różnej od pszenicy, tak że zgodnie z powszechną opinią nie może być nazwany chlebem pszennym, nie stanowi ważnej materii dla sprawowania Ofiary i sakramentu Eucharystii”"11.

Skoro Święta Kongregacja dla Sakramentów stwierdziła, że do ważności Eucharystii musi być chleb czysto pszenny, zaczęto się zastanawiać nad wytwarzaniem hostii bezglutenowych dla chorych na celiakię. W 1973 roku arcybiskup Liverpoolu George Andrew Beck (†13 IX 1978), po konsultacjach z teologami zezwolił na produkcję specjalnych hostii bez glutenu i poinformował swoich kapłanów, że mogą one być używane przy celebracji

\section{Zob. tamże.}

Io Por. tamże.

II Sacra Congregatio de Disciplina Sacramentorum, Instructio Dominus Salvator noster, 26 III 1929, nr 1, AAS, R. 21, 1929, s. 631-642. 
Eucharystii. Do roku 1982, każdego roku dostarczano około 40 tys. specjalnych hostii. Jednak co do tego pojawiły się wątpliwości (czy hostie te stanowią ważną materię Eucharystii) kierowane do Kongregacji Nauki Wiary, która 29 listopada 1982 roku nie wyraziła zgody na upoważnienie ordynariuszy miejscowych do wydawania zezwoleń na wypiekanie hostii bezglutenowych, które po konsekracji służyłyby jako Komunia Święta dla wiernych cierpiących na celiakię ${ }^{12}$.

Jednak biskupi w pewnych częściach świata nie byli zadowoleni odpowiedzią z 1982 roku z powodu dużej niewygody, jaką dla cierpiących na celiakię jest przyjmowanie Komunii Świętej pod postacią wina, i interweniowali w Kongregacji, aby tę kwestię rozpatrzono na nowo. Kongregacja w liście okólnym z 19 czerwca 1995 roku, skierowanym do wszystkich przewodniczących konferencji episkopatów w sprawie użycia chleba z niewielką zawartością glutenu i moszczu jako materii eucharystycznej, potwierdziła wcześniejszą wypowiedź, że specjalne hostie bezglutenowe (quibus glutinum ablatum est) są materią nieważną ${ }^{13}$.

Skoro hostie, z których usunięto gluten nie są ważną materią Eucharystii, to jakie jest rozwiązanie dla chorych na nietolerancję glutenu? Instrukcja Eucharisticum mysterium przypominała, że „w razie konieczności i wedle uznania biskupa wolno udzielać Komunii Świętej tylko pod postacią wina tym, co nie mogą jej przyjąć pod postacią chleba" ${ }^{14}$. Takie samo wyjaśnienie zawarte jest w Responsum ad propositum dubium Patres Sacrae Congregationis z 29 listopada 1982 roku $^{15}$.

Również aktualny kodeks w kan. 925 przewiduje taką możliwość, gdy postanawia: „Komunii Świętej należy udzielać [...] w wypadku konieczności, także tylko pod postacią wina”. Tak więc duchowni (celebransi) i świeccy chorzy na celiakię mogą przyjmować Komunię Świętą tylko pod postacią wina.

I2 Congregatio pro Doctrina Fidei, Responsum ad propositum dubium Patres Sacrae Congregationis, 29 XI 1982, nr II, 2, AAS, R. 74, 1982, s. 1298-1299 [dalej: Patres Sacrae Congregationis].

I3 Zob. Lettera circolare, nr I, B, 1.

I4 Sacra Congregatio Rituum, Instructio Eucharisticum mysterium de cultu Mysterii Eucharistici, 25 V 1967, nr 41, AAS, R. 59, 1967, s. 539-573.

is Zob. Patres Sacrae Congregationis, nr II, 1. 
Jeśli więc hostie bezglutenowe nie mogą być używane do celebracji Mszy św., to czy możliwe jest użycie hostii z niewielką zawartością glutenu, które ze swojej istoty są prawdziwym chlebem pszennym, a więc materią Eucharystii, spełniającą te same wymagania jakościowe, co tradycyjne pieczywo liturgiczne, czyli posiadających zasklepione brzegi (eliminujące kruszenie się opłatków)? Przede wszystkim, czy takie hostie można wyprodukować? Okazuje się, że tak, choć dużo drożej i wymaga to stworzenia specjalnej linii technologicznej.

Warunki odnośnie do ważności takiego pieczywa eucharystycznego podała Kongregacja Nauki Wiary w liście okólnym do przewodniczących konferencji episkopatów z 1995 roku.

Czytamy tam:

jeśli chodzi o pozwolenie na użycie chleba z niewielką zawartością glutenu:

A. Może być ono udzielone przez Ordynariuszy kapłanom i świeckim chorym na celiakię, po wcześniejszym przedstawieniu zaświadczenia lekarskiego.

B. Warunki ważności materii:

1. specjalne hostie „quibus glutinum ablatum est” są materią nieważną;

2. są natomiast materią ważną, jeśli jest w nich obecna ilość glutenu wystarczająca do otrzymania wypieku chleba, nie zostały dodane materie obce, a postępowanie zastosowane do ich otrzymania w żadnym wypadku nie zmienia istoty chleba ${ }^{16}$.

Cytowany list okólny nie mówi na temat pozwolenia diakonom na Komunię niskoglutenową, ale jest jasne, że skoro takie zezwolenie mogą otrzymać kapłani, to także i diakoni.

Gdy idzie o ilość glutenu w takich hostiach, to tradycyjny komunikant zawiera go $25 \mathrm{mg}$, natomiast w komunikancie niskoglutenowym firmy (jedynej w Polsce) Christiana - bracia Daniel i Michat Dąbrowscy z Opoczna jest 0,008 mg glutenu. Przypomnijmy, że dzienna, bezpieczna dawka glutenu w diecie chorych na celiakię nie powinna przekroczyć $10 \mathrm{mg}$.

Warunkiem otrzymania pozwolenia na komunikowanie niskoglutenowe jest przedstawieniu kompetentnemu ordynariuszowi zaświadczenia lekarskiego. Jest to zrozumiałe, gdyż taki sposób Komunii Świętej jest sytuacją

i6 Lettera circolare, nr I. 
wyjątkową, istnieje bowiem nadal możliwość przyjmowania przez te osoby Komunii Świętej pod postacią wina (KPK tylko taką możliwość przewiduje). Poza tym celiakia ma wiele odmian nietypowych, stąd kompetentny lekarz może orzec, czy konkretny wierny jest chory na tę chorobę, a w związku z tym, czy ma prawo komunikować niskoglutenowo.

Indywidualne zezwolenie na Komunię Świętą niskoglutenową w oparciu o zaświadczenie lekarskie jest konieczne, aby władza kościelna miała kontrolę nad tym sposobem komunikowania eucharystycznego. Wyrazem tego jest przepis Lettera circolare, że zainteresowane Konferencje Episkopatów powinny co dwa lata zdawać relację odnośnie do stosowania powyższych norm (dotyczących Komunii Świętej niskoglutenowej) Kongregacji ds. Kultu Bożego i Dyscypliny Sakramentów ${ }^{17}$.

Lettera circolare $\mathrm{w}$ normach wspólnych stanowi, iż ordynariusz powinien sprawdzić, czy używany produkt jest zgodny z podanymi wyżej wymaganiami. Firma Christiana-Dabrowscy z Opoczna posiada certyfikat z Zakładu Mikrobiologii i Immunologii Klinicznej Instytutu Pomnik-Centrum Zdrowia Dziecka w Warszawie dotyczący zawartości glutenu w wypiekanych przez nią hostiach. Ma także zezwolenie Biskupa Radomskiego na rozpowszechnianie wypiekanych hostii niskoglutenowych ${ }^{18}$.

Trzeba dodać, że hostie niskoglutenowe należy konsekrować na oddzielnej patenie. Przed udzieleniem Komunii Świętej osobom chorym na celiakię, szafarz powinien wypuryfikować palce, gdyż nawet bardzo małe cząsteczki chleba, pozostające na palcach podczas podnoszenia Hostii lub udzielania Komunii Świętej, zawierają szkodliwą ilość glutenu ${ }^{19}$.

Gdy idzie o kapłanów chorych na celiakię (która ujawniła się po przyjęciu prezbiteratu) celebrujących Mszę św., to w przeciwieństwie do tych, którzy mają pozwolenie na używanie moszczu, mogą oni przewodniczyć Mszy św. koncelebrowanej. Spożywają wtedy hostię niskoglutenową, podczas gdy koncelebransi hostię z normalną zawartością glutenu. Gdy chory jest koncelebransem, to sytuacja jest odwrotna.

${ }_{17}$ Tamże, nr III, E-F.

I8 Przypomnienie w sprawie materii Eucharystii, nr 10c.

19 Tamże, nr 10d. 


\section{Celiakia a kwestia dopuszczania do sakramentu święceń}

Dotychczas omówiono kwestię przyjmowania Komunii Świętej przez duchownych chorych na celiakię, ale w przypadkach, gdy pojawiła się ona już po przyjęciu konkretnego stopnia święceń. Pozostaje jedna ważna kwestia dopuszczania do święceń chorych na celiakię.

Lettera circolare zawiera wyraźny zapis: „kandydaci do kapłaństwa, którzy są chorzy na celiakię lub są dotknięci alkoholizmem lub analogicznymi chorobami, biorąc pod uwagę centralne miejsce celebracji eucharystycznej w życiu kapłańskim, nie mogą być dopuszczeni do Święceń" ${ }^{20}$. Pozornie wydaje się, że zapis ten zakłada nowy wymóg dotyczący zdatności kandydatów do święceń, tzn., że nie mogą oni chorować na alkoholizm albo celiakię. Jednak wymogu tego nie można nazywać przeszkodą do święceń. Bowiem przeszkody podane w KPK z 1983 roku w kan. 1041 i 1042 są wyliczone taksatywnie (kan. 1040). Żadne nieprawidłowości, czy też przeszkody zwykłe, nie mogą istnieć przez analogię. Ponieważ celiakia (albo alkoholizm) nie jest wyliczona w kan. 1041, 1042 albo 1044, cytowana norma z 1995 roku, stwierdzając, że ludzie z problemem alkoholizmu albo celiakią nie mogą być przeznaczeni do stanu duchownego, nie jest przeszkodą albo nieprawidłowością, ani nie może ona być utożsamiana z którąś z nich. Jaka jest więc natura i sens tej normy i jak ma być ona aplikowana? ${ }^{21}$

W przypadku celiakii trzeba brać pod uwagę różne sytuacje odnośnie do osób, które pragną wstąpić do seminarium, i które cierpią na celiakię. Czy nowy wymóg oznacza, że biskupi i wyżsi przełożeni zakonni mają odmówić odpowiednim kandydatom przyjęcia do seminarium, ponieważ cierpią oni na celiakię? Więcej, jaką możliwość wyboru ma biskup albo wyższy przełożony zakonny, jeżeli jeden z jego seminarzystów zachoruje na celiakię podczas formacji w seminarium? Czy, biorąc pod uwagę normy zawarte w przytoczonym wyżej liście Kongregacji Nauki Wiary z 1995 roku, można udzielić święceń kapłańskich mężczyźnie dotkniętemu chorobą celiakii?

Ponieważ sakrament święceń posiada trzy stopnie, to jawią się inne pytania: czy diakon przejściowy cierpiący na celiakię może być promowany

2o Lettera circolare, III, D.

2I Por. J. Wellspring, Coeliac Disease..., dz. cyt., s. 192. 
do święceń prezbiteratu. Ponadto, ponieważ konsekracja biskupia daje pełnię kapłaństwa, to czy w odniesieniu do prezbiterów istnieje przeszkoda w prezbiterzy z celiakią są przeszkodzeni w promowaniu na biskupów? ${ }^{22}$

Trzeba powiedzieć, że zakaz dopuszczania do kapłaństwa kandydatów chorych na celiakię wynika wyłącznie z nowej normy Lettera circolare z 1995 roku. Jak należy ten przepis interpretować? Czy jest to zakaz absolutny?

Ponieważ omawiana norma ogranicza swobodne wykonywanie uprawnień przez wiernych, to zgodnie z kan. 18 podlega ścisłej interpretacji. Ściśle zinterpretowana, norma ta ogranicza tylko kandydatów do kapłaństwa, którzy są chorzy na celiakię. Wyraźnie więc pozostawia otwartą możliwość przyjmowania kandydatów z tą chorobą do diakonatu stałego.

Także ścisła interpretacja tej normy nie stanowi zakazu w odniesieniu do wstępowania do seminarium kandydatów z celiakią, gdyż odnosi się tylko do dopuszczenia do święceń kapłańskich, a nie do formacji w seminarium. Jest przecież możliwe, że podczas pobytu alumna w seminarium opracowano by skuteczną terapię celiakii, z której mógłby on skorzystać, lub że sama choroba przeszłaby w stan remisji, albo że przed wyświęceniem na kapłana stałaby się dużo mniej uciążliwa ${ }^{23}$.

Ścisła interpretacja analizowanej normy jest też konieczna odnośnie do diakona przejściowego, który zachorował na celiakię i pragnie być promowany na kapłana. Ten, który był wyświęcony na diakona z zamiarem późniejszego wyświęcenia na kapłana, posiada implicite prawo, by być wyświęcony, jeżeli nie ma on przeszkody kanonicznej. Bowiem od dnia święceń diakońskich stosuje się do niego kan. 1030, w myśl którego ,jedynie na skutek kanonicznej przyczyny, chociaż tajnej, własny biskup lub kompetentny przełożony wyższy może zabronić przystąpienia do prezbiteratu własnym diakonom, przeznaczonym do kapłaństwa, z zachowaniem możności wniesienia rekursu, zgodnie z prawem”. Chociaż cytowany przepis kodeksowy nie daje wyraźnie kandydatowi prawa do święceń kapłańskich, to jednak implikuje takie prawo. W ten sposób prawo chroni racjonalne oczekiwanie kandydatów do stopnia prezbiterów, dotyczące przejścia z diakonatu na wyższy stopień sakramentu święceń. Odmowa kandydatowi takiego święcenia to bardzo poważna sprawa, co potwierdza wyraźna gwarancja prawa do rekursu przeciw

\footnotetext{
${ }^{22}$ Por. tamże.

23 Por. tamże, s. 208.
} 
takiej decyzji. Kanon mówi, że tylko z kanonicznej przyczyny, takiej jak przeszkoda, nieprawidłowość (kan. 1041-1042) albo cenzura, mogłaby kompetentna władza odmówić dopuszczenia do prezbiteratu ${ }^{24}$.

Kolejnym etapem interpretacji omawianej normy jest ustalenie prawnego waloru Lettera circolare.

Wspomniany list ma charakter prawny, a nie doktrynalny. To implikuje jakieś wcześniejsze, doktrynalne określenie materii, jako podstawy dla norm listu, choć sam okólnik nie mówi, w jaki sposób zostało to dokonane. Można przypuszczać, że w odniesieniu do tego punktu doktryny żadna ostateczna decyzja nie była podjęta, ponieważ mogłaby to uczynić tylko najwyższa władza kościelna, Papież i Kolegium Biskupów (por. kan. 841), a nie jedynie Kongregacja Doktryny Wiary. Do takich decyzji po Soborze Watykańskim II należy zaliczyć nowe określenie istotnego obrzędu bierzmowania dokonane przez papieża Pawła VI ${ }^{25}$. Publikując tę normę, Kongregacja przypuszczalnie musiała wywnioskować, że skoro Magisterium Kościoła podtrzymuje, iż chleb pszenny wymagany do Eucharystii nie może być pozbawiony wystarczającej ilości glutenu koniecznego dla jego wypie$\mathrm{ku}$, to chleb, z którego usunięto cały gluten jest nieważną materią. Tak więc chociaż list okólny implikuje i sugeruje tego rodzaju doktrynalne określenie, sam list jest z natury prawny, a nie doktrynalny ${ }^{26}$.

Skoro omawiany dokument ma charakter jurydyczny, to jaka jest jego ranga prawna? Trzeba powiedzieć, że dokumenty prawne wydawane przez Stolicę Apostolską posiadają pewną hierarchię odnoszącą się do ich doniosłości kanonicznej. Najważniejsze są dokumenty ustawodawcze, które zawierają ustawy (kan. 7) i dekrety ogólne (kan. 29). Następnymi aktami są dokumenty administracyjne ogłoszone dla wspólnoty, które zawierają ogólne dekrety wykonawcze (kan. 31-33). Na niższym poziomie sytuują się dokumenty administracyjne wiążące wykonawców prawa, które zawierają normy nazywane instrukcjami (kan. 34). W końcu istnieją pewne dokumenty prawne, które nie są wiążące. Ostatnia kategoria nas tu nie interesuje, gdyż omawiany list

24 Por. M. Pastuszko, Sakrament święceń (kanony 1008-1054), Kielce 2008, s. 317318.

25 Paulus VI, Constitutio Apostolica Divinae consortium naturae, 15 VIII 1971, AAS, R. 63, 1971, s. 657-664; por. J. Wellspring, Coeliac Disease..., dz. cyt., s. 209.

26 Por. J. Wellspring, Coeliac Disease..., dz. cyt., s. 209. 
okólny zamieszcza normy, które z natury wiążą. Powstaje pytanie: do jakiej z trzech kategorii dokumentów należy analizowany okólnik?

Jest oczywiste, że rozpatrywany okólnik nie jest dokumentem ustawodawczym. Gdyby Kongregacja Doktryny Wiary chciała wydać ustawę, to musiałaby uzyskać zlecenie od papieża na wydanie dekretu ogólnego (kan. 29-30), ale tego nie uczyniono ${ }^{27}$. Kongregacja mogła także postarać się o papieską aprobatę listu w formie specjalnej (in forma specifica), ale tego również nie zrobiono. Dokument nie był nawet zatwierdzony przez papieża w sposób ogólny (in forma communi). Lettera circolare nie ma również prawnej wartości ogólnych dekretów wykonawczych, które, podobnie jak ustawy, są wydane dla wspólnoty i muszą być promulgowane (kan. 31). Omawiany list nie był ogłoszony w „Acta Apostolicae Sedis”, lecz wysłany do przewodniczących konferencji biskupów i opublikowany w „Notitiae”28.

Z tego, co powiedziano, wynika tylko jedna konkluzja: normy listu okólnego z 1995 roku mają rangę instrukcji. Jego treść odpowiada dokładnie naturze instrukcji. Kan. $34 \$ 1$ stanowi: „instrukcje, które mianowicie wyjaśniają przepisy ustaw oraz rozwijają i określają racje, które należy uwzględnić przy ich zachowaniu, są dane na użytek tych, którzy mają się troszczyć o wprowadzenie ustaw w życie i obowiązują ich w wykonywaniu ustaw. Wydają je zgodnie z prawem w granicach swojej kompetencji ci, którzy posiadają władzę wykonawczą". List jest zaadresowany głównie do ordynariuszy, którzy mają obowiązek wykonać to prawo. Dalej, jako tekst wyjaśniający i zawarty w nim zestaw norm, list ukazuje, w jaki sposób prawo ma być zrealizowane. Odmiennie od ustaw i ogólnych dekretów wykonawczych, instrukcje nie potrzebują promulgacji.

Jest znaczące, że normy listu skierowane są głównie do ordynariuszy, w szczególności biskupów diecezjalnych albo wyższych przełożonych kleryckich instytutów zakonnych i stowarzyszeń życia apostolskiego na prawie papieskim, którzy są ordynariuszami seminarzystów albo diakonów pragnących zostać prezbiterami. Ordynariusze ci mają prawo aprobować kandydatów do święceń i wystawiać dymisorie. Jedynie ordynariusz jest bezpośrednio zobowiązywany przez list, nie cała wspólnota, nie seminarzysta czy diakon

27 Por. R. Sobański, Komentarz do kan. 29, [w:] Komentarz do Kodeksu Prawa Kanonicznego, t. 1: Księga 1. Normy ogólne, red. J. Krukowski, Poznań 2003, s. 88.

28 Por. J. Wellspring, Coeliac Disease..., dz. cyt., s. 210. 
dążący do święceń, ani nawet wyświęcający biskup, jeżeli nie jest on ordynariuszem kandydata do święceń. Taka konkluzja wynika z natury norm mających postać instrukcji. One nie mogą wiązać kogoś innego, jak tylko wykonawcę prawa, w tym przypadku ordynariuszy, którzy mają prawo promować kandydatów do święceń i wydawać dymisorie.

Znaczenie norm okólnika z 1995 roku jako instrukcji (kan. 34) ma dalsze implikacje. Kan. 34, $\$ 2$ stanowi: „postanowienia instrukcji nie zmieniają ustaw. Jeśli zaś któreś z nich nie dadzą się pogodzić z przepisami ustaw, są pozbawione wszelkiej mocy”. Jakakolwiek norma w administracyjnym dokumencie Kurii Rzymskiej, która jest przeciwna prawu powszechnemu jest pozbawiona wszelkiej mocy ${ }^{29}$. Czy norma listu, która zabrania chorym na celiakię przyjęcia święceń kapłańskich jest przeciwna kan. 1029 KPK, który zostawia właściwemu biskupowi albo wyższemu przełożonemu osąd w sprawie zdatności kandydatów do święceń?

Gdy idzie o prawo ordynariusza dotyczące dopuszczania do święceń, to musi brać on pod uwagę kan. 1029 mówiący o przymiotach kandydatów do święceń.

Przepis ten brzmi:

do święceń należy dopuszczać jedynie tych, którzy - według roztropnej oceny własnego biskupa albo kompetentnego przełożonego wyższego - po rozważeniu wszystkich okoliczności, mają nieskażoną wiarę, kierują się prawidłową intencją, posiadają wymaganą wiedzę, cieszą się dobrą opinią, mają nienaganne obyczaje, wypróbowane cnoty, jak również inne przymioty fizyczne i psychiczne, odpowiadające przyjmowanemu święceniu ${ }^{30}$.

Przytoczony kanon wymaga, aby osoba promowana do święceń była oceniana przez kompetentny autorytet kościelny jako posiadająca określone przymioty: nieskażoną wiarę, prawidłową intencję, wymaganą wiedzę, winna cieszyć się dobrą opinią, mieć nienaganne obyczaje, wypróbowane cnoty, jak również inne przymioty fizyczne i psychiczne, odpowiadające przyjmowanemu święceniu. Chociaż kanon określa wymagane przymioty, to robi to raczej

29 Por. R. Sobański, Komentarz do kan. 34, [w:] Komentarz do Kodeksu Prawa Kanonicznego, t. 1: Księga 1. Normy ogólne, dz. cyt., s. 93.

3o Zob. M. Pastuszko, Sakrament święceń..., dz. cyt., s. 297-299. 
ogólnie, aniżeli wylicza konkretne warunki. Stopień, w jakim kandydat posiada te przymioty, jest pozostawiony roztropnemu osądowi własnego biskupa lub kompetentnego przełożonego wyższego ${ }^{31}$.

Jeśliby co do któregokolwiek z tych warunków istniały uzasadnione wątpliwości, decyzja o udzieleniu albo odmówieniu promowania do święceń należałaby do wymienionej kompetentnej władzy. Inaczej niż w przypadku zwykłej albo trwałej przeszkody, kandydat, któremu odmówiono promocji, miałby prawo rekursu przeciw decyzji odmawiającej mu święceń na podstawie braku przymiotu (przymiotów) wspomnianych w kan. 1029.

W podejmowaniu jakiejkolwiek decyzji o dopuszczeniu do święceń kandydata cierpiącego na celiakię ordynariusz musi brać pod uwagę ogólne wymagania wyszczególnione w kan. 1029. Rozważając, czy kandydat z celiakią odpowiada przymiotom fizycznym do święceń, biskup albo kompetentny przełożony musi uznać, że ogólnie tacy kandydaci nie mogą być dopuszczani do święceń kapłańskich i zgodnie z logiką, konsekwentnie, nie powinni być przyjmowani do seminarium, chyba że przygotowują się do diakonatu stałego.

To prawda, że norma okólnika z 1995 roku jasno wyraża intencję Kongregacji Doktryny Wiary, że mężczyźni, którzy cierpią na celiakię (i alkoholizm) nie powinni być wyświęcani na kapłanów. Trzeba jednak przyznać, że norma ta nie odbiera ordynariuszom prawa do decydowania odnośnie do poszczególnych kandydatów, jak ustala kan. 1029.

Nie jest więc wykluczone, że konkretny ordynariusz może ocenić, iż jest możliwy wyjątek względem tej normy w przypadku szczególnym, że może zaistnieć sytuacja, w której normę można by zachować, bez odmawiania święceń kapłańskich zdatnemu kandydatowi, choremu na celiakię. Faktycznie, ordynariusz mógłby sądzić, że niewłaściwe albo nawet szkodliwe dla dobra powszechnego (np. z powodu braku kapłanów) byłoby kierowanie się tą normą z bezwarunkową surowością w przypadku szczególnym. W takiej sytuacji ordynariusz może zdecydować, że normy listu okólnego z 1995 roku nie da się zastosować w szczególnej sytuacji, jednak pod warunkiem, że istnieje pewność, iż mężczyzna może spożywać przynajmniej porcję hostii niskoglutenowej, tak aby mógł przewodniczyć koncelebrze eucharystycznej.

31 $\quad$ Por. J. Wellspring, Coeliac Disease..., dz. cyt., s. 211. 
Kodeks przecież, jako prawo powszechne, promulgowane przez najwyższego ustawodawcę, ma wyższą rangę prawną niż list okólny. Kodeks ma pierwszeństwo nad dokumentami władzy wykonawczej. Ponieważ prawo powszechne daje kompetentnemu biskupowi albo wyższemu przełożonemu prawo do decydowania, czy kandydat jest zdatny do święceń (kan. 1029), a prawo to nie może być im odebrane przez normę administracyjną, jeżeli nie jest zatwierdzona przez papieża w określonej formie, to z tego wynika, że list okólny z 1995 roku nie może być rozumiany jako ograniczający właściwą swobodę ordynariuszy odnośnie do odpowiedniości ich kandydatów do święceń. W przeciwnym razie byłoby to sprzeczne z kodeksem i nie miałoby mocy obowiązującej (kan. $34 \$ 2)^{32}$.

Pozostaje jeszcze problem promowania prezbitera chorego na celiakię do biskupstwa. Normy omawianego listu nie czynią żadnej wzmianki dotyczącej tej materii, ani nie jest to konieczne. Tylko do papieża bowiem należy promowanie księży do episkopatu po uprzednim mianowaniu albo potwierdzeniu ich wyboru dokonanego zgodnie z prawem (kan. $377 \$ 1$ ). On nie jest ograniczony do wyboru tylko tych prezbiterów, którzy są wolni od celiakii. Biskup Rzymu ma bowiem najwyższą i pełną władzę i nie jest związany przez akty niższej władzy wykonawczej (kan. 331) ${ }^{33}$.

\section{Wnioski}

1. Celiakia (choroba trzewna) to trwająca całe życie immunologiczna choroba o podłożu genetycznym, charakteryzująca się nietolerancją glutenu, białka zapasowego zawartego w zbożach (pszenicy, życie, jęczmieniu, owsie). W efekcie toksycznego działania glutenu wchłanianie pokarmu jest upośledzone, co prowadzi do wystąpienia różnorodnych objawów klinicznych natury somatycznej i psychicznej, często niebezpiecznych dla zdrowia i życia.

2. Ponieważ materią Eucharystii jest chleb wyłącznie z pszennej mąki bez żadnych dodatków, a do natury takiego chleba należy gluten, stąd chorzy na chorobę trzewną nie mogą przyjmować Komunii Świętej pod postacią chleba. Bowiem typowa hostia komunijna dla rozdania wiernym zawiera

32 Por. tamże, s. 210-213.

33 Por. tamże, s. 213. 
między 2,2 a 2,5 miligrama gliadyny, a liczne hostie zawierają między 11,9 i 12,7 miligrama gliadyny, podczas gdy dobowa dawka tego białka dla chorych wynosi średnio 10 miligramów.

3. Ponieważ hostie bezglutenowe są nieważną materią Eucharystii, wierni: kapłani (po przyjęciu święceń) i świeccy chorzy na celiakię za zgodą kompetentnego ordynariusza, po wcześniejszym przedstawieniu zaświadczenia lekarskiego, mogą uzyskać pozwolenie na przyjmowanie konsekrowanych hostii z niewielką zawartością glutenu.

4. W kwestii dopuszczania do święceń kapłańskich (nie do diakonatu stałego) kandydaci do kapłaństwa, którzy są chorzy na celiakię, biorąc pod uwagę centralne miejsce celebracji eucharystycznej w życiu kapłańskim, nie mogą być dopuszczeni do święceń.

5. W przypadkach szczególnych kompetentna władza kościelna, ze względu na dobro wspólne (np. z powodu braku kapłanów) mogłaby zdecydować się na dopuszczenie chorych na celiakię do prezbiteratu pod warunkiem, iż zdatny diakon (przejściowy) pragnący przyjąć prezbiterat może spożywać przynajmniej porcję hostii niskoglutenowej, tak aby mógł przewodniczyć koncelebrze eucharystycznej.

\section{Coeliac Disease and the Sacrament of Holy Orders}

Summary

People who suffer from coeliac disease cannot receive Holy Communion under the species of bread.

The article starts with explaining the characteristics and phenomenon of coeliac disease. Then it discusses the possibility of receiving Holy Communion by people with the condition. Finally, it raises the question of admitting persons with coeliac disease to the sacrament of Holy Orders.

Keywords: coeliac disease, Holy Communion, sacrament of Holy Orders, ordination, deacon, priest, bishop, gluten, low gluten bread 